\title{
Two new nematode species of the genus Paratrilobus Micoletzky, 1922 (Nematoda, Triplonchida) from the water area of Lake Baikal (Russia)
}

\author{
Tatyana V. NAUMOVA ${ }^{1 *} \&$ Vladimir G. GAGARIN ${ }^{2}$ \\ ${ }^{1}$ Limnological Institute Siberian Branch of the Russian Academy of Sciences, \\ Irkutsk, 664033, Russia. \\ ${ }^{2}$ Institute for Biology of Inland Waters, Russian Academy of Sciences, \\ Borok, Yaroslavl Province, 152742, Russia. \\ *Corresponding author: tvnaum@lin.irk.ru \\ 2Email: gagarin@ibiw.ru \\ ${ }^{2}$ https://orcid.org/0000-0001-9825-3177 \\ ${ }^{1}$ urn:1sid:zoobank.org:author:835C52CB-795C-48BF-B5A0-6DA2C303E060
}

\begin{abstract}
This paper describes and illustrates two new nematode species of the genus Paratrilobus Micoletzky, 1922. The species Paratrilobus tankhoyensis sp. nov. was found at the estuary of the Pereyomnaya River (water area of Lake Baikal, near the Tankhoy railway station). Paratrilobus tankhoyensis sp. nov. is most similar to P. expugnator (Tsalolichin, 1976) in the body size, but differs in the comparatively thin body, shorter and thicker tail, shorter stoma and spicules. Another new species, Paratrilobus aquaticus sp. nov., was found in Posolsk Bank (natural underwater elevation of the bottom between the southern and central basins of Lake Baikal). The species is similar to P. granulosus Gagarin \& Naumova, 2011 and P. ultimus (Tsalolichin, 1977) in the structure of the precloacal supplements. It differs from the former in the absence of crystalloids, a comparatively longer pharynx, longer stoma and outer labial setae as well as the absence of subterminal seta. It differs from the latter in a longer pharynx, stoma and longer outer labial setae as well as a longer and more slender tail. We also discuss diagnostic features of the males of the genus Paratrilobus.
\end{abstract}

Keywords. Free-living nematodes, diversity, morphology, taxonomy.

Naumova T.V. \& Gagarin V.G. 2020 Two new nematode species of the genus Paratrilobus Micoletzky, 1922 (Nematoda, Triplonchida) from the water area of Lake Baikal (Russia). European Journal of Taxonomy 723 : 159-172. https://doi.org/10.5852/ejt.2020.723.1151

\section{Introduction}

The genus Paratrilobus belongs to the family Tobrilidae Filipjev, 1918 (De Coninck, 1965). According to Hodda (2011), the world's tobrilid fauna includes 162 species in 10 genera. More than 45 species of the Tobrilidae inhabit Lake Baikal (Naumova \& Gagarin 2019a, Naumova \& Gagarin 2019b). 
The Hungarian nematologist Istvan Andrássy (2007) included eight valid species in the genus Paratrilobus: P. brevis (Tsalolichin, 1976), P. delicatus (Shoshin, 1988), P. expugnator (Tsalolichin, 1976), P. grandipapilloides Micoletzky, 1922, P. ponticus Tsalolichin, 1981, P. rapis Gagarin, 1991, P. strenuus (Gagarin, 1991) and P. ultimus (Tsalolichin, 1977). Later, one more species, P. granulosus Gagarin \& Naumova, 2011, was described from Lake Baikal (Gagarin \& Naumova 2011).

This paper aims to describe two new nematode species from the water area of Lake Baikal (P. tankhoyensis sp. nov. and $P$. aquaticus sp. nov.) and discuss some features of the genus Paratrilobus.

\section{Material and methods}

Nematodes were collected from the following two sites: water area of Lake Baikal, estuary of the Pereyomnaya River, near the Tankhoy railway station, (51.568452 N, $105.166531 \mathrm{E}), 10 \mathrm{~cm}$ depth, collected on 19 July 2018; southern basin of Lake Baikal, Posolsk Bank (underwater elevation of the bottom between the southern and central basins, (52.07994 N, $105.90368 \mathrm{E}), 51 \mathrm{~m}$ depth, sand and silt, collected on 5 July 2012.

The samples contained numerous free-living nematodes, including the species described herein. Nematodes were fixed by standard methods and mounted in glycerin on permanent slides. All observations were made using Olympus CX-21 and Nikon Eclipse 80i light microscopes with Nomarski DIC accessories. Images were taken using a Nikon DS-Fil digital camera and Intel Pentium Dual CPU E 2200 Processor Series for Desktop with the NIS-Elements D 3.2 program for analysis and documentation of images from the preparations.

\section{Institutional abbreviations}

HM RAS = Helminthological Museum, Center for Parasitology, Institute of Ecology and Evolution, Russian Academy of Science, Moscow, Russia

LIN-SB = Limnological Institute, Siberian Branch, Russian Academy of Sciences, Irkutsk, Russia

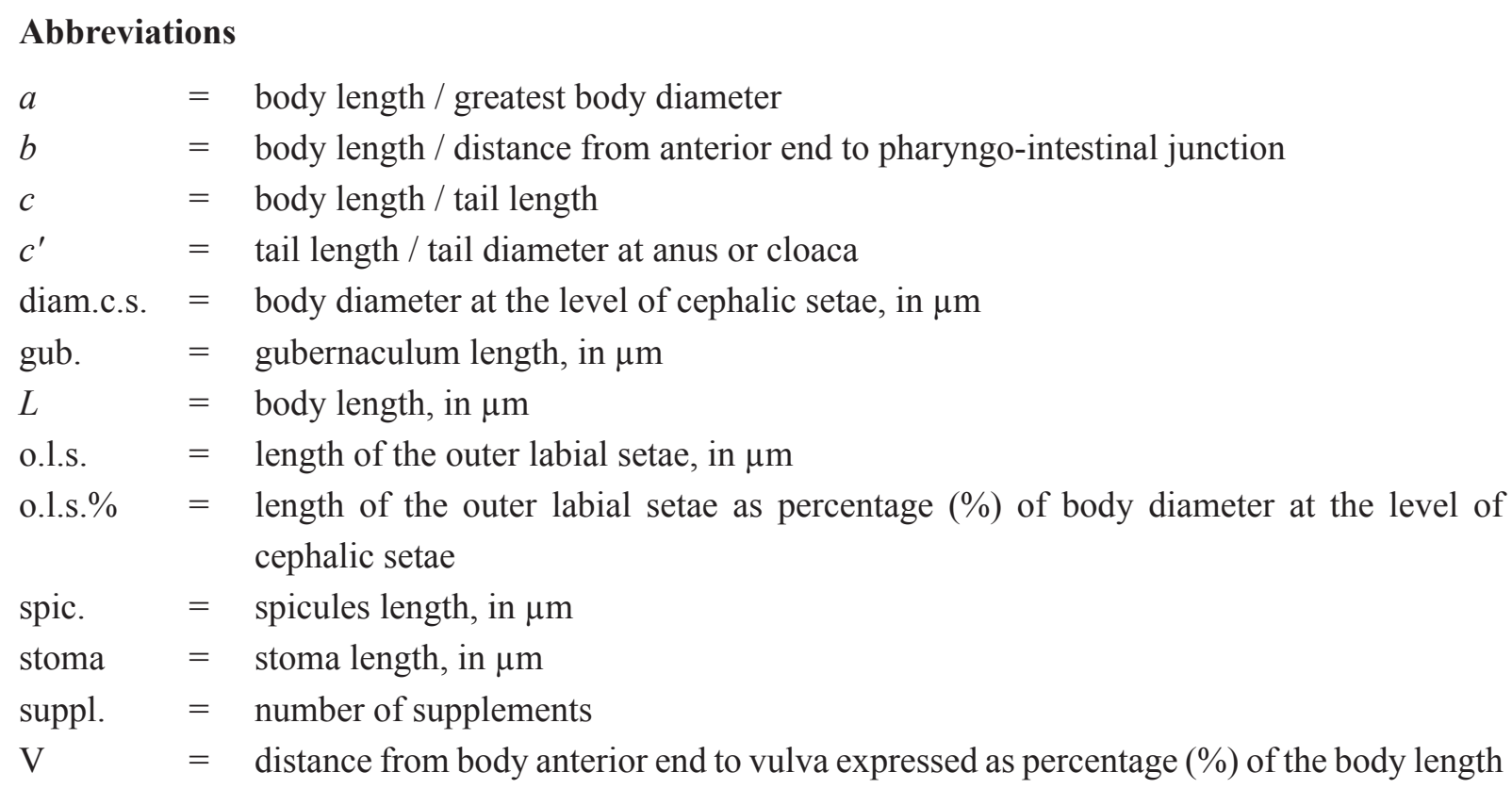




\title{
Results
}

\author{
Phylum Nematoda Cobb, 1932 \\ Class Enoplea Inglis, 1983 \\ Order Triplonchida Cobb, 1920 \\ Family Tobrilidae Filipjev, 1918 (De Coninck, 1965) \\ Genus Paratrilobus Micoletzky, 1922
}

\section{Type species}

Paratrilobus grandipapilloides Micoletzky, 1922.

Diagnosis (after Andrássy 2007)

Body 1.9-5.5 mm long. Amphidial fovea at the stoma level. Buccal cavity spacious, funnel- or barrelshaped with well-sclerotized walls. Pockets merged with buccal cavity, practically reduced. Teeth small, at base of stoma or just posterior to it. Vagina normal. Supplements six, rarely seven to eight, echinate, large, protractible; first and last supplements usually smaller than others.

Paratrilobus tankhoyensis sp. nov.

urn:1sid:zoobank.org:act:D13C061E-EE0E-4A58-B706-3E4256774FFF

Figs 1-2, Table 1

\section{Diagnosis}

Paratrilobus tankhoyensis sp. nov. is characterized by a 3687-5463 $\mu \mathrm{m}$ long body; cuticle smooth under light microscope; crystalloids absent; inner labial sensillae in shape of short and thick setae $6-10 \mu \mathrm{m}$ long; six outer labial sensillae in shape of smooth non-articulated setae 27-33 $\mu \mathrm{m}$ long, 54-67\% of labial region width for males and $44-56 \%$ for females; four cephalic sensillae in shape of thin and smooth setae 12-15 $\mu \mathrm{m}$ long; buccal cavity spacious, barrel-shaped. One pocket merged with buccal cavity; two small teeth located in stoma base. Spicules comparatively thin and long (70-76 $\mu \mathrm{m}$ in length), 1.2-1.6 times as long as cloacal body diameter; gubernaculum in shape of 'gutter'; precloacal supplements 6-7 in number, comparatively large, echinate; 'cap' and 'shoulder' well developed; supplemental ampulla comparatively large; its contents located in top part of ampulla; first and last supplements smaller than others; tail elongate-conical, comparatively thick, with subterminal seta.

\section{Etymology}

The species epithet means 'from Tankhoy', the type locality name.

\section{Material examined}

Holotype

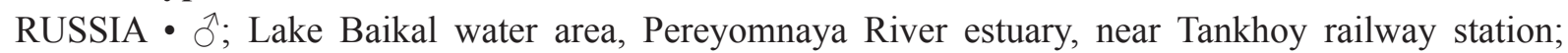
$51.568452^{\circ} \mathrm{N}, 105.166531^{\circ} \mathrm{E}$; $10 \mathrm{~cm}$ depth; 19 Jul. 2018; T.V. Naumova leg.; sand; HM RAS, slide $102 / 71(1538-2)$.

\section{Paratypes}

RUSSIA • 1 $\hat{\delta}, 2$ + $O$; same collection data as for the holotype; T.V. Naumova leg.; HM RAS, slide 102/71 (1538-1, 1538-3, 1538-4) • $8 \widehat{\partial} \widehat{\partial}, 8$ 우 9 same collection data as for the holotype; T.V. Naumova leg.; LIN-SB. 


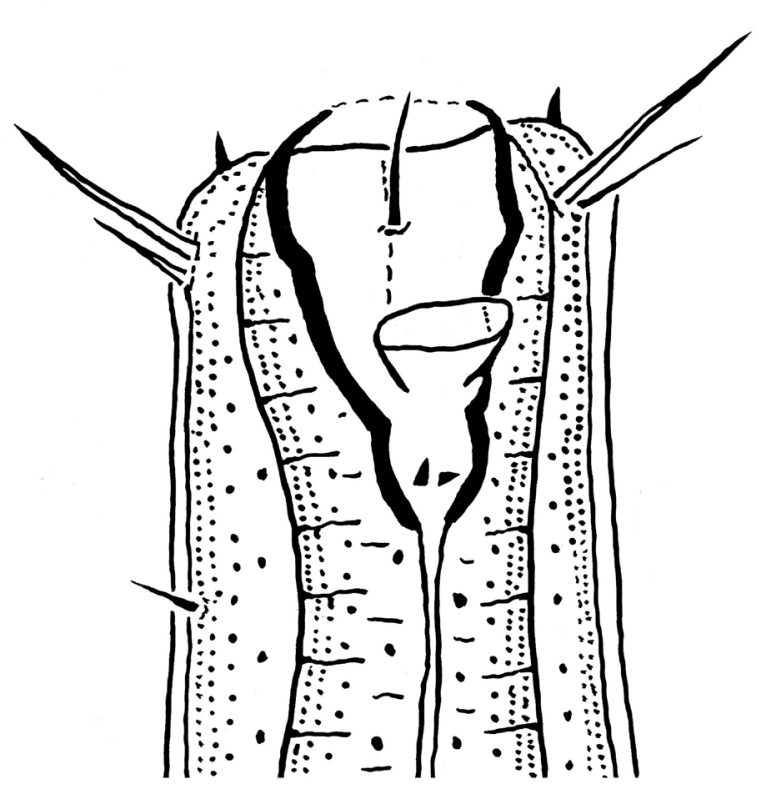

$\mathbf{A}$
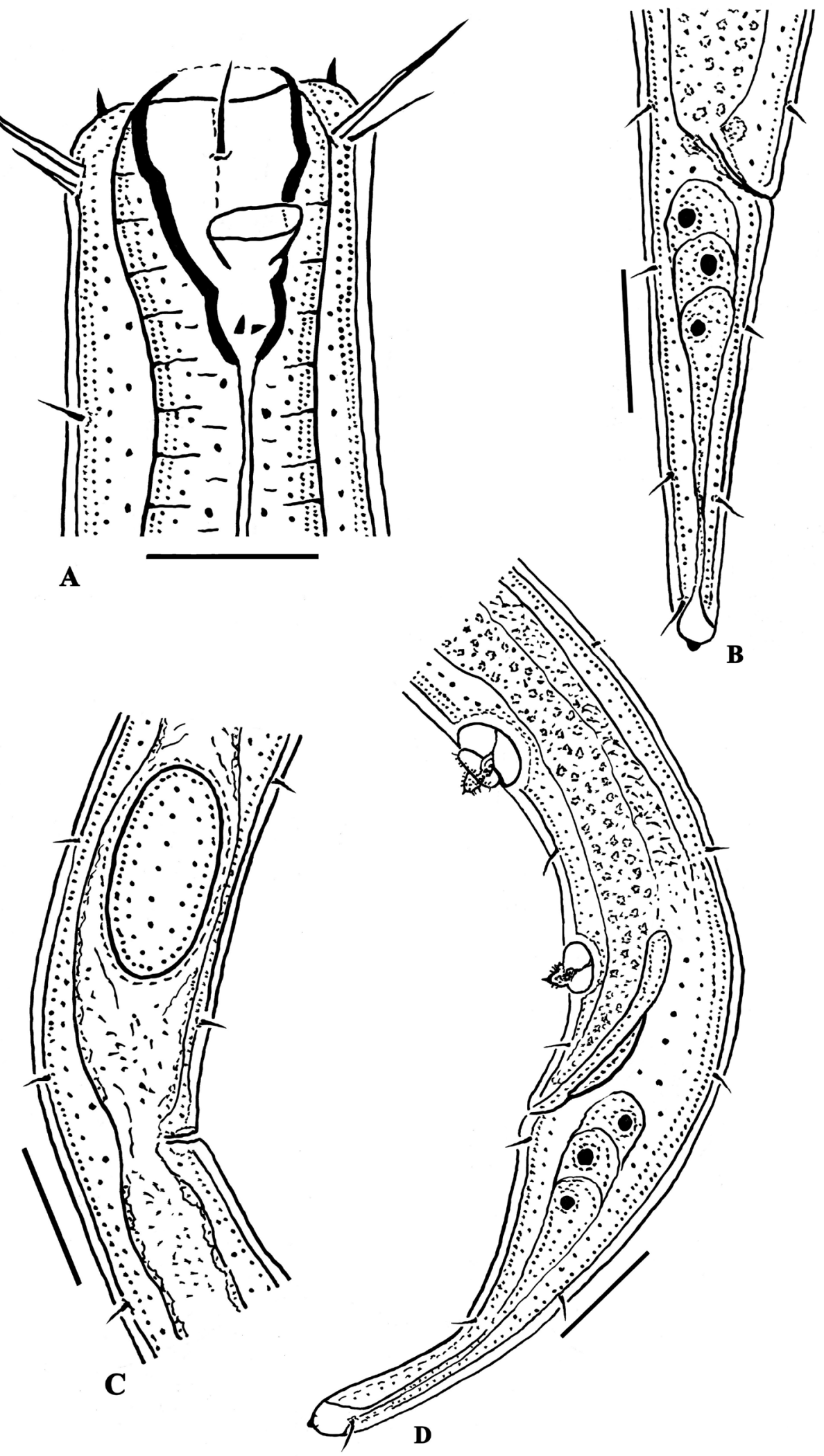

Fig. 1. Paratrilobus tankhoyensis sp. nov. A. Male anterior end. B. Female posterior end. C. Female vulva region. D. Male posterior body end. A, D: holotype (HM RAS 102/71 1538-2); B-C: paratype (HM RAS 102/71 1538-1). Scale bars: $A=30 \mu \mathrm{m} ; \mathrm{B}=60 \mu \mathrm{m} ; \mathrm{C}=80 \mu \mathrm{m} ; \mathrm{D}=40 \mu \mathrm{m}$. 

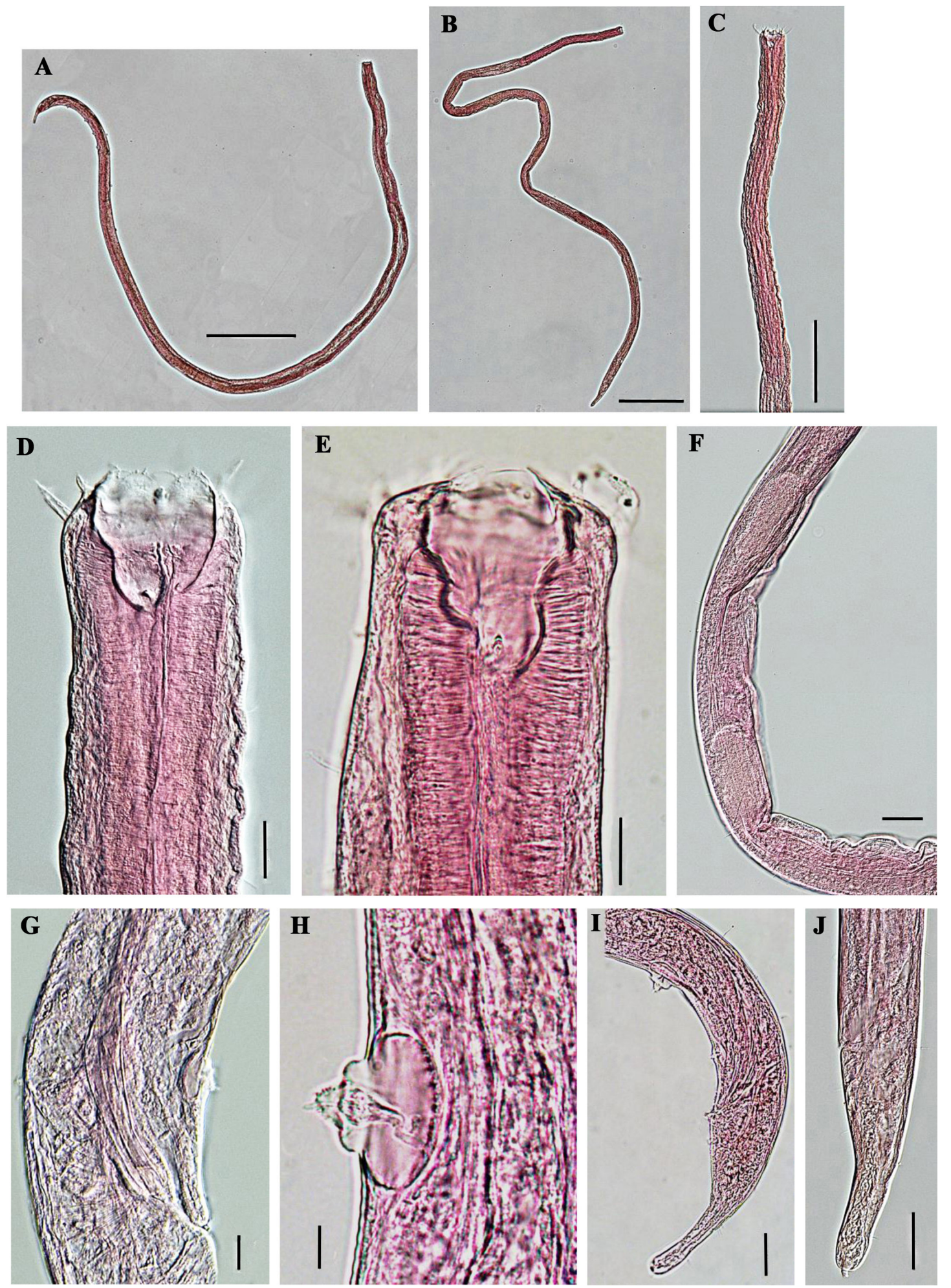

Fig. 2. Paratrilobus tankhoyensis sp. nov., light micrographs. A. Entire male. B. Entire female. C. Male pharyngeal region. D. Male anterior end. E. Female anterior end. F. Female vulva region. G. Male cloacal region. H. Male precloacal supplement. I. Male posterior body end. J. Female posterior body end. A, H-I: holotype (HM RAS 102/71 1538-2); B, E, J: paratype (HM RAS 102/71 1538-3); C-D, G: paratype (HM RAS 102/71 1538-4), F: paratype (HM RAS 102/71 1538-1). Scale bars: A-B = $500 \mu \mathrm{m}$; $\mathrm{C}-\mathrm{E}=20 \mu \mathrm{m} ; \mathrm{F}, \mathrm{I}-\mathrm{J}=50 \mu \mathrm{m} ; \mathrm{G}-\mathrm{H}=10 \mu \mathrm{m}$. 
Table 1. Measurements (in $\mu \mathrm{m}$ ) of Paratrilobus tankhoyensis sp. nov., presented as mean and range.

\begin{tabular}{|c|c|c|c|}
\hline Character & Holotype ${ }^{\lambda}$ & $\hat{\partial} \hat{O}$ & 우인 \\
\hline Number of specimens & 1 & 10 & 10 \\
\hline Body length (L) & 4265 & $4323(3687-4793)$ & $4923(4130-5463)$ \\
\hline$a$ & 64 & $65(59-71)$ & $63(57-67)$ \\
\hline$b$ & 5.9 & $5.7(5.1-5.9)$ & $5.8(5.4-6.3)$ \\
\hline$c$ & 33 & $32(25-38)$ & $25(23-28)$ \\
\hline$c^{\prime}$ & 2.5 & $2.6(2.3-3.0)$ & $3.4(2.9-3.7)$ \\
\hline $\mathrm{V}, \%$ & - & - & $48(47-52)$ \\
\hline Labial region diameter & 50 & $50(45-55)$ & $60(53-67)$ \\
\hline Body diameter & 67 & $67(60-77)$ & $78(70-90)$ \\
\hline Anal or cloacal diameter & 52 & $52(48-60)$ & $59(52-70)$ \\
\hline Stoma length & 45 & $46(45-48)$ & $51(50-55)$ \\
\hline Outer labial setae length & 27 & $30(28-31)$ & $30(28-33)$ \\
\hline Cephalic setae length & 12 & $14(13-15)$ & $13(12-15)$ \\
\hline Pharynx length & 725 & $765(725-838)$ & $854(762-960)$ \\
\hline Posterior pharynx end to vulva & - & - & $1524(1300-1688)$ \\
\hline Posterior pharynx end to cloaca & 3410 & $3424(2812-3830)$ & - \\
\hline Vulva to anus & - & - & $2350(1888-2638)$ \\
\hline Tail length & 130 & $136(125-150)$ & $196(180-220)$ \\
\hline Spicula length & 75 & $74(70-76)$ & - \\
\hline Gubernaculum length & 38 & $35(35-38)$ & - \\
\hline Number of supplements & 6 & $6-7$ & - \\
\hline
\end{tabular}

\section{Description}

\section{Male}

Body comparatively long, thin. Cuticle smooth under light microscope, 1.5-2.0 $\mu \mathrm{m}$ thick. Body diameter at posterior pharynx end 1.3-1.4 times as large as width of labial region. Crystalloids absent. Somatic setae sparse, short, $8-11 \mu \mathrm{m}$ long. Labial region slightly offset from adjacent body; lips well developed. Six inner labial sensillae in shape of thick, short setae, 6-9 $\mu \mathrm{m}$ long. Six outer labial sensillae in shape of smooth non-articulated setae, long $54-67 \%$ of labial region width. Four cephalic sensillae in shape of thin, smooth setae. Cheilostom of average size. Buccal cavity spacious, barrel-shaped, with thick walls. One pocket offset from buccal cavity, on its base two small teeth. Stoma 0.9 times as long as labial region width. Amphidial fovea cup-shaped, opening at level of buccal cavity. Pharynx muscular, comparatively long, expanding gradually along entire length. Cardiac glands large, rounded, 22-25 $\mu \mathrm{m}$ in diameter. Ventral gland, its canal, ampulla, excretory pore not seen.

Testes paired, situated to left of intestine; anterior testis outstretched, posterior testis reflexed. Vas deferens well developed. Spicules comparatively thin, slightly curved, long, 1.2-1.6 times as long as cloacal body diameter. Gubernaculum in shape of 'gutter', $46-50 \%$ of spicule length. Precloacal supplements 6-7 in number, first, last supplements smaller than others. Supplement ampulla comparatively large, its contents located in top part of ampulla. Supplements comparatively large, echinate, 'cap', 'shoulder' 
well developed. Supplement row 475-588 $\mu \mathrm{m}$ long. Precloacal supplement located at spicules level. Tail elongate-conical, comparatively thick, with subterminal seta. Caudal glands well developed; spinneret in shape of short conical tube.

\section{Female}

General morphology similar to males in structure of cuticle, anterior body end. Six inner labial sensillae in shape of thick and short setae, $8-10 \mu \mathrm{m}$ long. Outer labial sensillae in shape of smooth non-articulated setae, long $44-56 \%$ of labial region width. Cardia small, surrounded by three round glands. Prerectum not observed. Rectum length equal to or slightly less than anal body diameter. Reproductive system didelphic, amphidelphic. Ovaries situated to left of intestine, reflexed, comparatively short. Oocytes numerous. Vulva transverse slit, situated to mid-body or slightly anterior to mid-body. Vulval lips not sclerotized, not protruding outside body contour. Cuticular wrinkles around vulva, vulva glands not seen. Vagina short, with thick walls. Uterus containing numerous spermatozoa, 1-2 eggs, measuring 112-132 $\times 52-80 \mu \mathrm{m}$. Tail elongate-conical, comparatively thick, with subterminal seta. Caudal glands well developed.

\section{Remarks}

Paratrilobus tankhoyensis sp. nov. is most similar to P. expugnator (Tsalolichin, 1976) in body size (Tsalolichin 1976). The new species differs from it in the comparatively thin body ( $a=57-71$ vs $a=$ 32-44 in P. expugnator), shorter and thicker tail $\left(c=23-38, c^{\prime}=2.3-3.7\right.$ vs $c=8.2-10.4, c^{\prime}=5.0-7.5$ in P. expugnator), shorter stoma (stoma length $45-55 \mu \mathrm{m}$ vs $70-80 \mu \mathrm{m}$ long in $P$. expugnator), and shorter spicules (spicules length 70-76 $\mu \mathrm{m}$ vs $90 \mu \mathrm{m}$ long in P. expugnator) (Tsalolichin 1976).

Paratrilobus aquaticus sp.nov.

urn:1sid:zoobank.org:act:AB5F0913-BB36-403D-A732-AEFBB93CA939

Figs 3-4, Table 2

\section{Diagnosis}

Paratrilobus aquaticus sp. nov. is characterized by a $2015-2203 \mu \mathrm{m}$ body length; cuticle finely annulated; crystalloids absent; six inner labial sensillae papilliform; six outer labial sensillae in the shape of smooth non-articulated setae 18-20 $\mu \mathrm{m}$ long (53-58\% of labial region width); four cephalic sensillae in shape of thin and smooth setae 10-13 $\mu \mathrm{m}$ long; buccal cavity spacious, barrel-shaped; one pocket connected with buccal cavity by wide gleam and contains two small teeth. Spicules comparatively thin, $51 \mu \mathrm{m}$ long, 1.2 times as long as cloacal body diameter; gubernaculum in shape of 'gutter'. Precloacal supplements 6 in number, about same size, located approximately at identical distance from each other; supplements echinate, not very protruded over body surface; contents of ampulla located at base; cap armed, numerous small thorns and one large central thorn. Tail slender, comparatively long; three caudal glands and spinneret well developed; subterminal seta not observed.

\section{Etymology}

The species epithet comes from the habitat ('water').

\section{Material examined}

\section{Holotype}

RUSSIA $-{ }^{7}$; Lake Baikal, Posolsk Bank (underwater elevation of the bottom between the southern and central basins of Lake Baikal); $52.07994^{\circ} \mathrm{N}, 105.90368^{\circ} \mathrm{E}$; $51 \mathrm{~m}$ depth; 5 Jul. 2012; T.V. Naumova leg.; sand and silt; HM RAS, slide 102/64 (768-2). 

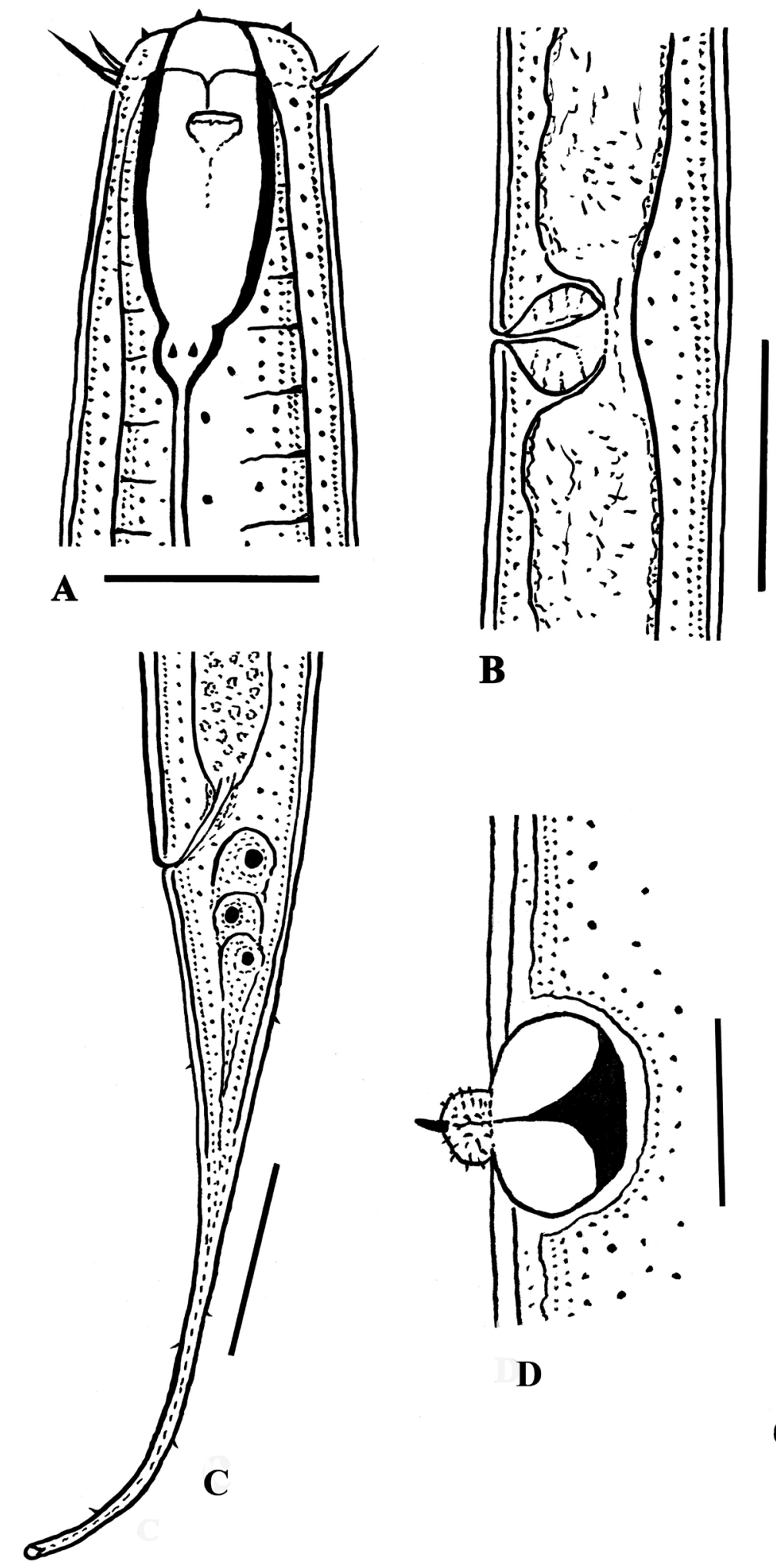

B

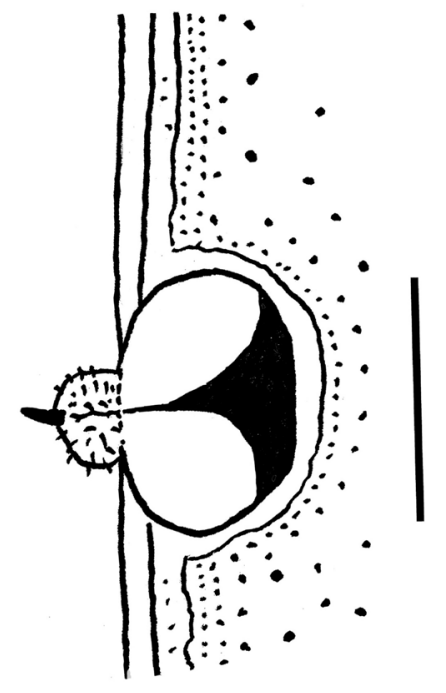

D

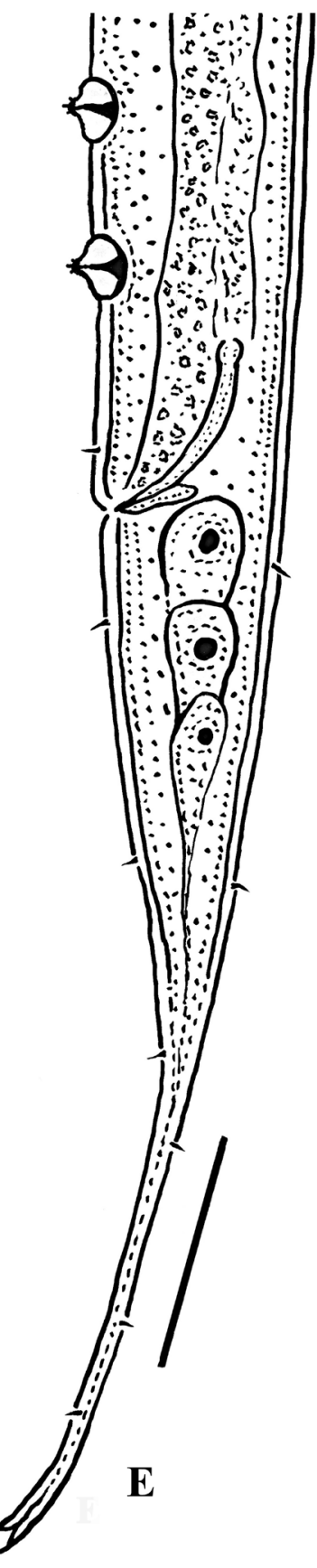

Fig. 3. Paratrilobus aquaticus sp. nov. A. Male anterior end. B. Female vulva region. C. Female posterior body end. D. Male precloacal supplement. E. Male posterior body end. A, D-E: holotype (HM RAS 102/64 768-2); B-C: paratype (HM RAS 102/64 768-4). Scale bars: A = $30 \mu \mathrm{m}$; B = $70 \mu \mathrm{m}$; $\mathrm{C}=60 \mu \mathrm{m} ; \mathrm{D}=20 \mu \mathrm{m} ; \mathrm{E}=50 \mu \mathrm{m}$. 

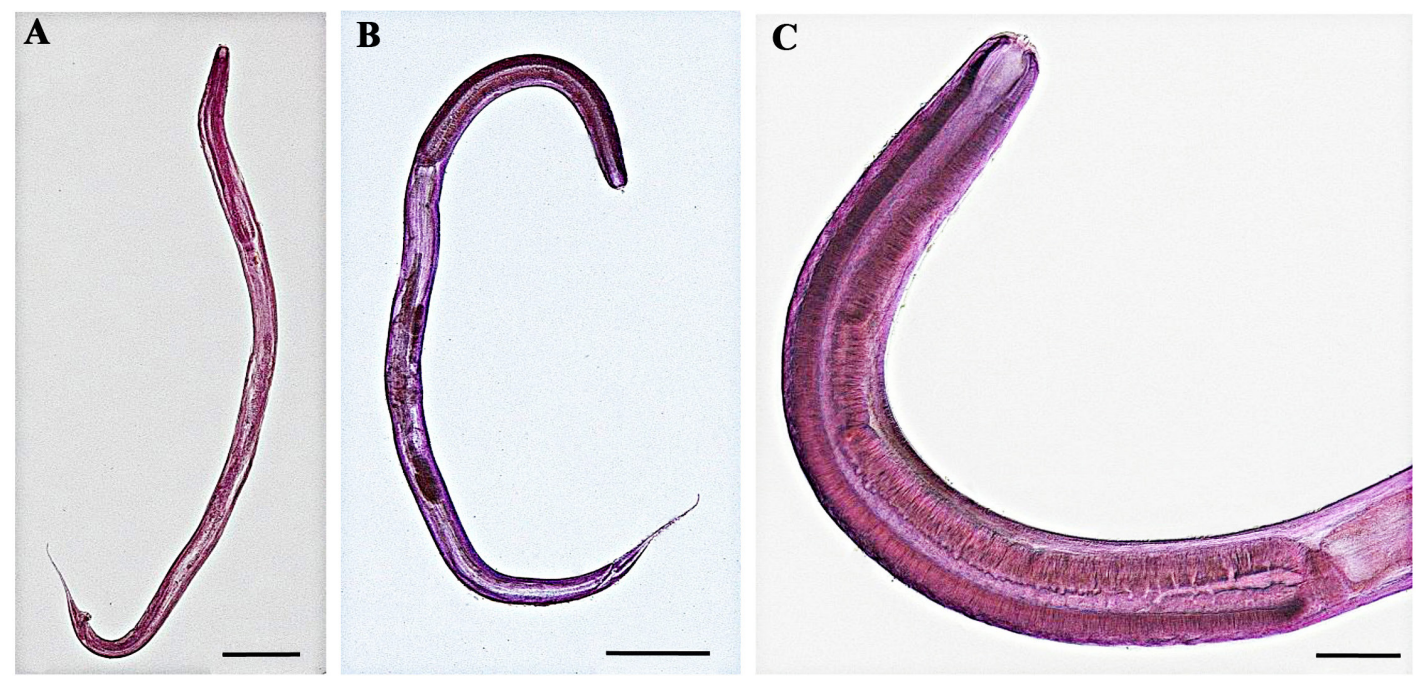

D

$\mathbf{E}$
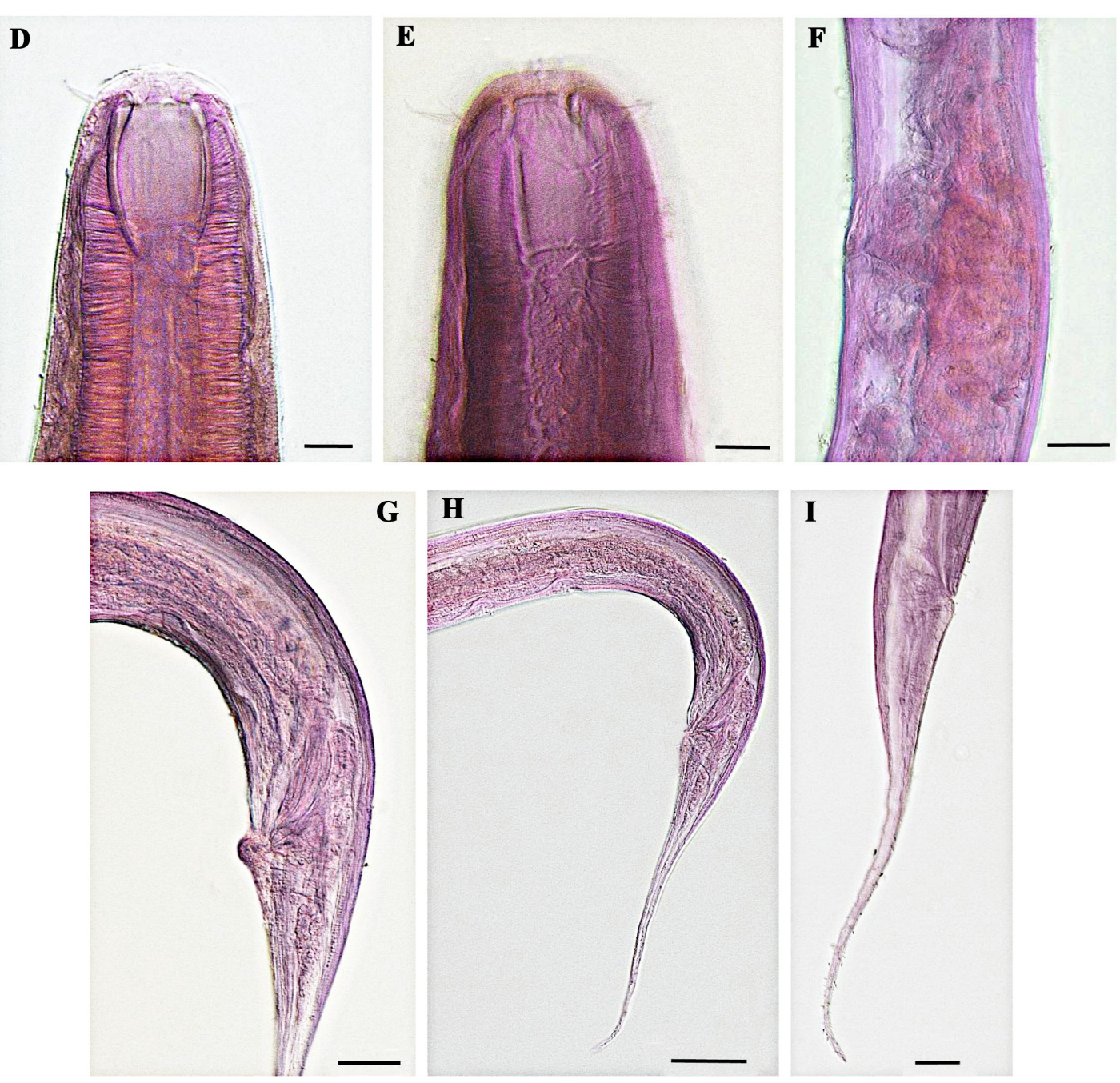

Fig. 4. Paratrilobus aquaticus sp. nov., light micrographs. A. Entire male. B. Entire female. C. Female pharyngeal region. D. Male anterior end. E. Female anterior end. F. Female vulva region. G. Male cloacal region. H. Male posterior body end. I. Female posterior body end. A, D, G-H: holotype (HM RAS 102/64 768-2); B-C, I: paratype (HM RAS 102/64 768-4); E-F: paratype (LIN-SB 765-3). Scale bars: $\mathrm{A}-\mathrm{B}=200 \mu \mathrm{m} ; \mathrm{C}, \mathrm{H}=50 \mu \mathrm{m} ; \mathrm{D}-\mathrm{E}=10 \mu \mathrm{m} ; \mathrm{F}-\mathrm{G}, \mathrm{I}=20 \mu \mathrm{m}$. 
Table 2. Measurements (in $\mu \mathrm{m}$ ) of Paratrilobus aquaticus sp. nov., presented as mean and range.

\begin{tabular}{lcc}
\hline Character & Holotype & Paratypes + \\
\hline Number of specimens & 1 & 4 \\
Body length (L) & 2097 & $2079(2015-2203)$ \\
$a$ & 28 & $29(26-30)$ \\
$b$ & 3.9 & $3.4(3.3-3.7)$ \\
$c$ & 8.9 & $8.3(7.5-8.8)$ \\
$c^{\prime}$ & 5.3 & $6.3(6.0-6.8)$ \\
V, \% & - & $52.4(51.8-53.0)$ \\
Labial region diameter & 34 & $33(31-35)$ \\
Body diameter & 75 & $72(68-80)$ \\
Anal or cloacal diameter & 43 & $41(39-43)$ \\
Stoma length & 50 & $50(48-52)$ \\
Outer labial setae length & 18 & $19(18-20)$ \\
Cephalic setae length & 11 & $12(10-13)$ \\
Pharynx length & 536 & $609(589-630)$ \\
Posterior pharynx end to vulva & - & $479(434-578)$ \\
Posterior pharynx end to cloaca & 1326 & - \\
Vulva to anus & - & $738(697-787)$ \\
Tail length & 235 & $253(240-267)$ \\
Spicula length & 51 & - \\
Gubernaculum length & 20 & - \\
Number of supplements & 6 & - \\
\hline
\end{tabular}

\section{Paratypes}

RUSSIA • 3 우; same collection data as for the holotype; T.V. Naumova leg.; LIN-SB (765-3, 765-5, 767-5) 1 o same collection data as for the holotype; T.V. Naumova leg.; HM RAS slide 102/64 (768-4).

\section{Description}

\section{Male}

Body comparatively short. Cuticle finely annulated, $1.5 \mu \mathrm{m}$ thick. Crystalloids absent. Somatic setae sparse, short. Labial region comparatively high, slightly offset from adjacent body, lips well developed. Six inner labial sensillae papilliform. Six outer labial sensillae in shape of smooth setae long $53 \%$ of labial region width. Four cephalic sensillae in shape of thin setae. Cheilostom of average size. Buccal cavity spacious, barrel-shaped, with thick walls. One pocket connected with buccal cavity by wide gleam, containing two small teeth. Stoma 1.5 times as long as labial region width. Amphidial fovea cupshaped, opening at level of buccal cavity. Pharynx muscular, comparatively long, expanding gradually along length. Cardiac glands large, rounded, $30 \mu \mathrm{m}$ in diameter. Ventral gland, its canal, ampulla, excretory pore not observed.

Testes paired, situated to left of intestine; anterior testis outstretched, posterior testis short, reflexed. Vas deferens well developed. Spicules slender, ventral curved, 1.2 times as long as cloacal body diameter. 
Gubernaculum in shape of gutter, 39\% of spicule length. Precloacal supplement 6 in number, about one size, located approximately at equal distances from each other. Supplements echinate, not very protruded over body surface. Ampulla contents concentrated in ampullae base. Shoulder absent. Cap armed, numerous small thorns, one large central thorn. Precloacal supplement located anteriorly to spicules level. Tail slender, comparatively long. Three caudal glands, spinneret well developed. Subterminal setae not seen.

\section{Female}

General morphology similar to that of males in structure of cuticle, anterior body end. Six outer labial sensillae in shape of smooth non-articulated setae long 53-58\% of labial region width. Cardia surrounded by three round glands. Rectum length equal to or slightly greater than anal body diameter. Reproductive system didelphic, amphidelphic. Ovaries situated to left of intestine, reflexed. Oocytes numerous. Vulva transverse slit, situated slightly posterior to mid-body. Vulval lips not sclerotized, not protruded outside body contour. Cuticular wrinkles around vulva, vulva glands not observed. Vagina straight line, with well-expressed spherical vaginal chamber, thick walls. Generated eggs in uterus not observed. Tail slender, comparatively long. Subterminal seta not seen.

\section{Remarks}

Paratrilobus aquaticus sp. nov. is similar to P. granulosus Gagarin \& Naumova, 2011 and P. ultimus (Tsalolichin, 1977) in the structure of the precloacal supplements. From the former species, it differs in the absence of crystalloids, a comparatively longer pharynx ( $b=3.3-3.9$ vs $b=4.5-5.9$ in P. granulosus), longer outer labial setae $(18-20 \mu \mathrm{m}$ long, $53-58 \%$ of labial region width vs $6.5-8.5 \mu \mathrm{m}$ long, 30 $35 \%$ of labial region width in $P$. granulosus $)$, the vulva position $(\mathrm{V}=51.8-53.0 \%$ vs $39.1-46.1 \%$ in P. granulosus), the longer stoma (48-52 $\mu \mathrm{m}$ long vs 28-33 $\mu \mathrm{m}$ long in P. granulosus), and the absence of a subterminal seta (Gagarin \& Naumova 2011). From the latter species, it differs in the longer pharynx ( $b=3.3-3.9$ vs $b=4.7-5.9$ in P. ultimus $)$, a longer and more slender tail $\left(c=7.5-8.9, c^{\prime}=5.5-6.8\right.$ vs $c=10.9-16.4, \mathrm{c}^{\prime}=3.5-4.5$ in P. ultimus), the longer stoma (48-52 $\mu \mathrm{m}$ long vs $21 \mu \mathrm{m}$ in P. ultimus), longer outer labial setae (18-20 $\mu \mathrm{m}$ long, 53-58\% of labial region width $v s$ 6-7 $\mu \mathrm{m}$ long, $25-30 \%$ of labial region width in P. ultimus), and the vulva position ( $\mathrm{V}=51.8-53.0 \% \mathrm{vs} \mathrm{V}=39-43 \%$ in P. ultimus) (Tsalolichin 1977).

\section{Discussion}

We compared males of valid species of the genus Paratrilobus (except for P. rapis described only from females) according to morphological characters (Table 3). On grounds of the supplement structure, the genus can be divided into two species groups:

1) comparatively large supplements with 'shoulder', cap and ampulla contents located in the top part of ampulla (P. grandipapilloides, $P$. brevis, $P$. delicatus, $P$. expugnator, P. ponticus and $P$. tankhoyensis sp. nov., i.e., 'grandipapilloides' species group)

2) comparatively small supplements; 'shoulder' is absent, cap comparatively small, ampulla contents located in ampulla base (P. ultimus, P. granulosus, P. aquaticus sp. nov., i.e., 'ultimus' species group).

We cannot give the rank of subgenus to these groups, but we must take into account the heterogeneity of the genus.

The species P. strenuus was found in Lake Tajmyr (Siberia, Russia) and was originally described from 32 females as Eutobrilus strenuus Gagarin, 1991 (Gagarin 1991). Subsequently, the species was transferred to the genus Quasibrilus Tsalolichin, 1976, because the buccal cavity in specimens of this species is small, one pocket with two small teeth is hardly visible and well isolated from the buccal 


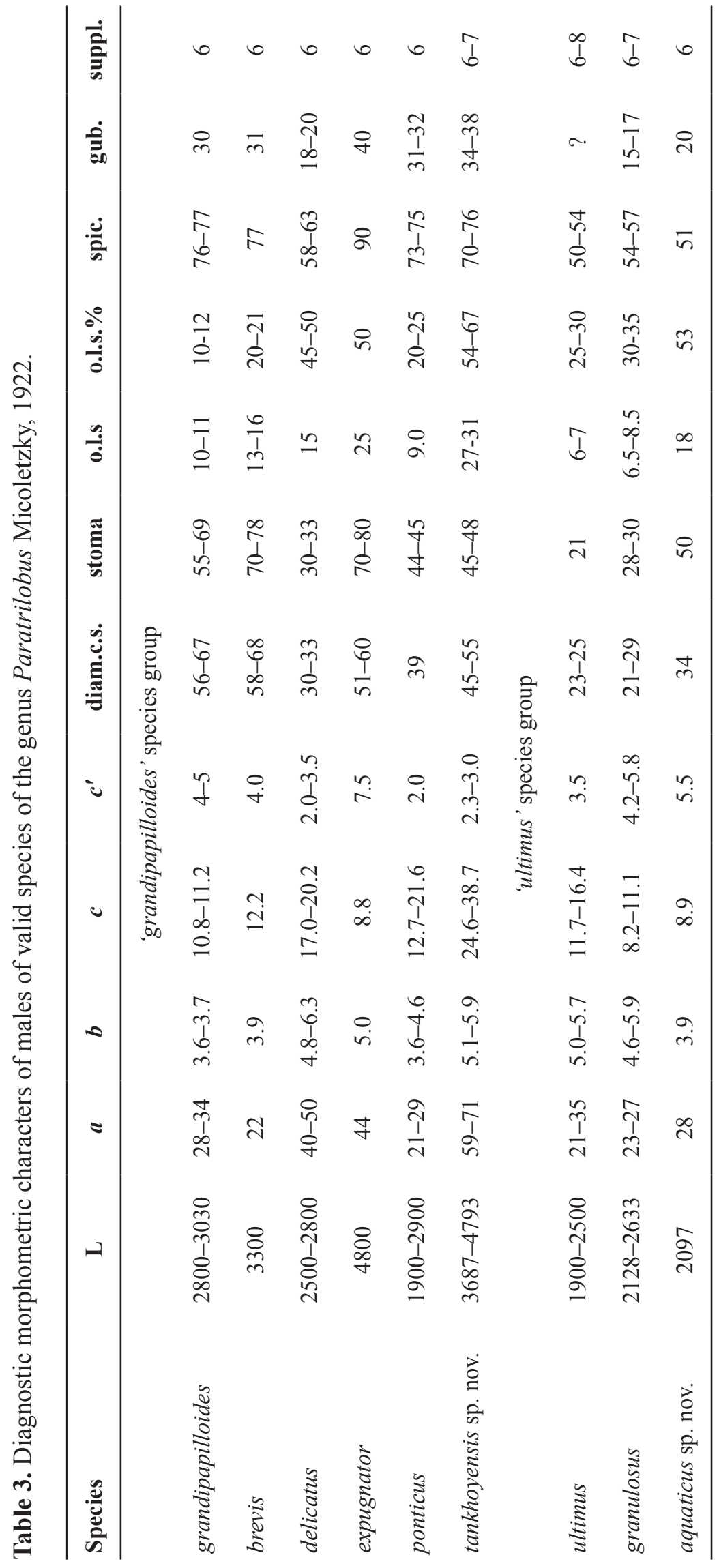


cavity (Gagarin 1993). Andrássy (2007) placed this species in the genus Paratrilobus, but we consider this an erroneous decision and return this species to the genus Quasibrilus, because a stoma structure in this species does not correspond to the morphological diagnosis of the genus Paratrilobus (Andrássy 2007). The main feature of the genus Paratrilobus is the buccal cavity structure: it is spacious, funnel- or barrel-shaped with well-sclerotized walls; pockets are almost reduced.

The distribution area of the genus is within the borders of Eurasia. Paratrilobus grandipapilloides was described from freshwater bodies of Germany (Micoletzky 1922), but later, it was also found in Lake Onega, Lake Tajmyr and Lake Baikal (Gagarin 1990; Zullini 2006; Naumova \& Gagarin 2019a). Paratrilobus ponticus was known from Dnepro-Bugs estuary of the Black Sea (Tsalolichin 1981). Paratrilobus rapis was described from Lake Tajmyr (Siberia, Russia) (Gagarin 1991). Seven species of the genus were found and described from Lake Baikal (Naumova \& Gagarin 2019a). Therefore, Lake Baikal is the largest natural centre of speciation of this genus.

\section{Acknowledgements}

The work was supported by the Russian State Tasks No. AAAA-A16-116122110067-8 and No. AAAA-A15-118012690105-0. The authors are grateful Dr Vladimir A. Gusakov (Institute for Biology of Inland Waters Russian Academy of Sciences) for assistance in preparing microphotographs.

The English version was partially revised and translated by Julia M. Vitushenko.

\section{References}

Andrássy I. 2007. Free-living Nematodes of Hungary (Nematoda Errantia). II. Hungarian Natural History Museum and Systematic Zoology Research Group of the Hungarian Academy of Sciences, Budapest.

Gagarin V.G. 1990. Free-living Nematodes Fauna of the Taimyr Peninsula Waterbodies and Observations on the Species Complexes of Nematodes in Freshwaters. In: Fauna, Biology and Systematics of Freeliving lower Worms. Institute for Biology of Inland Waters USSR Academy of Sciences, Rybinsk. [In Russian.]

Gagarin V.G. 1991. Nematodes of family Tobrilidae (Enoplida) from the Arctic water bodies. Zoologicheskii Zhurnal 70: 11-21. [In Russian.]

Gagarin V.G. 1993. Free-living Nematodes of Freshwater in Russia and Adjacent Countries (Orders Monhysterida, Araeolaimida, Chromadorida, Enoplida, Mononchida). St.-Petersburg, Gidrometeoizdat. [In Russian.]

Gagarin V.G. \& Naumova T.V. 2011. Paratrilobus granulosus sp. n., Tobrilus longisetosus sp. n. and Domorganus acutus (Tsalolikhin, 1977) from Lake Baikal, Russia. International Journal of Nematology 21: 85-95.

Hodda M. 2011. Phylum Nematoda Cobb 1932. In: Zhang Z.-Q. (ed.) Animal Biodiversity: An Outline of higher-level Classification and Survey of Taxonomic Richness. Zootaxa 3148: 63-96. https://doi.org/10.11646/zootaxa.3148.1.11

Micoletzky H. 1922. Freie Nematoden aus dem Grundschlamm norddeutscher Seen. Archiv für hydrobiology 13: 532-560.

Naumova T.V. \& Gagarin V.G. 2019a. Review of the free-living Nematode (Nematoda) fauna of Lake Baikal. Zootaxa 4608(1): 101-118. https://doi.org/10.11646/zootaxa.4608.1.5 
Naumova T.V. \& Gagarin V.G. 2019b. Two new nematode species of the genus Tobrilus Andrássy, 1959 (Nematoda, Triplonchida) from Lake Baikal, Russia. European Journal of Taxonomy 579: 1-13. https://doi.org/10.5852/ejt.2019.579

Tsalolikhin S. Ya. 1976. New species of nematodes of the order Enoplida in the Baikal Lake. Zoologicheskii Zhurnal 55: 346-353. [In Russian.]

Tsalolikhin S.Ya. 1977. New species of nematodes from Baikal Lake. Zoologicheskii Zhurnal 56: 989995. [In Russian.]

Tsalolikhin S.Ya. 1981. A revision of the genus Tobrilus (Nematoda, Tobrilidae). Zoologicheskii Zhurnal 9: 1302-1313. [In Russian.]

Zullini A. 2006. Order Triplonchida. In: Eyualem-Abebe A.I. \& Traunspurger W. (eds) Freshwater Nematodes. Ecology and Taxonomy. CABI-publishing, Wallingford, UK.

Manuscript received: 2 July 2020

Manuscript accepted: 17 September 2020

Published on: 16 November 2020

Topic editor: Rudi Jocqué

Desk editor: Jeroen Venderickx

Printed versions of all papers are also deposited in the libraries of the institutes that are members of the EJT consortium: Muséum national d'histoire naturelle, Paris, France; Meise Botanic Garden, Belgium; Royal Museum for Central Africa, Tervuren, Belgium; Royal Belgian Institute of Natural Sciences, Brussels, Belgium; Natural History Museum of Denmark, Copenhagen, Denmark; Naturalis Biodiversity Center, Leiden, the Netherlands; Museo Nacional de Ciencias Naturales-CSIC, Madrid, Spain; Real Jardín Botánico de Madrid CSIC, Spain; Zoological Research Museum Alexander Koenig, Bonn, Germany; National Museum, Prague, Czech Republic. 